\title{
Analysis of the spleen proteome of chickens infected with reticuloendotheliosis virus
}

\author{
Mei Xue ${ }^{1} \cdot$ Yan Zhao $^{1} \cdot$ Shunlei $\mathrm{Hu}^{1} \cdot \mathrm{Xingming} \mathrm{Shi}^{1} \cdot \mathrm{Hongyu}^{\mathrm{Cui}}{ }^{1} \cdot$ \\ Yunfeng Wang ${ }^{1,2}$
}

Received: 1 August 2016/Accepted: 19 November 2016/Published online: 17 January 2017

(C) The Author(s) 2017. This article is published with open access at Springerlink.com

\begin{abstract}
Infection with reticuloendotheliosis virus (REV), a gammaretrovirus in the family Retroviridae, can result in immunosuppression and subsequent increased susceptibility to secondary infections. In the present study, we identified differentially expressed proteins in the spleens of chickens infected with the REV-A HLJ07I strain, using two-dimensional gel electrophoresis on samples from time points coinciding with different phases of the REV life cycle. Differentially expressed proteins were identified using one-dimensional liquid chromatography electrospray ionization tandem mass spectrometry (1D LC ESI MS/ MS). Comparative analysis of multiple gels revealed that the majority of changes occurred at early stages of infection. In total, 60 protein spots representing 28 host proteins were detected as either quantitatively (false discovery rate [FDR] $\leq 0.05$ and fold change $\geq 2$ ) or qualitatively differentially expressed at least once during different sampling points. The differentially expressed proteins identified in this study included antioxidants, molecular chaperones, cellular metabolism, formation of the cytoskeleton, signal transduction, cell proliferation and cellar aging. The present findings provide a basis for further studies to elucidate the role of these proteins in REV-host interactions. This
\end{abstract}

M. Xue and Y. Zhao contributed equally to this paper.

Yunfeng Wang

wangyunfeng02@caas.cn

1 State Key Laboratory of Veterinary Biotechnology, Harbin Veterinary Research Institute, The Chinese Academy of Agricultural Sciences, Harbin 150001, People's Republic of China

2 National Engineering Research Center of Veterinary Biologics, Harbin, People's Republic of China could lead to a better understanding of REV infection mechanisms that cause immune suppression.

\section{Introduction}

Reticuloendotheliosis viruses (REVs) are a group of viruses in the family Retroviridae, specifically, gammaretroviruses in the same genus as mammalian C-type retroviruses [12]. The REV group includes defective REV$\mathrm{T}[32,33]$, non-defective REV-A [11, 75], chick syncytial virus [14], duck infectious anemia virus [41], and spleen necrosis virus (SNV) [66]. REVs cause immunosuppression, runting disease, and lymphoma in a variety of avian hosts, including chickens, turkeys, ducks, geese, pheasants, peafowl, and some other bird species [7]. The immunosuppression caused by REV infection increases the susceptibility to concurrent or secondary bacterial or viral infections and results in poor immune responses to other vaccines $[38,80]$. REV can co-infect with other viruses [17] and cause contamination of a variety of poultry biologics [31]. In addition, REV integrates easily into the host genome, and it has been associated with a number of hematopoietic cell tumors $[37,76]$. Therefore, REV poses a serious threat to the poultry industry.

Knowledge of the interactions between virus and host is critical for understanding the pathogenesis of viral infection. The expression of host cellular proteins changes greatly during retroviral infection, from the entry of the virus to incorporation of viral DNA into the host genome, and finally to the release of virions. By applying comparative proteomics techniques, changes in the expression profile of cellular proteins during viral infections can be monitored, which may help to further elucidate viral 
pathogenesis [63]. Proteomics studies using a human immunodeficiency virus (HIV)-infected monocyte/macrophage lineage were the first to be applied in a retrovirus infection [39]. However, the utilization of twodimensional gel electrophoresis (2-DE) to investigate the proteomic changes that occur in REV-A-infected chickens has not been reported.

The present study was designed to examine the spleen proteome of specific-pathogen-free (SPF) chickens in the course of infection with an REV-A strain. To address this objective, several time points were selected for harvesting tissues that corresponded to important phases of REV pathogenesis. A total of 28 differentially expressed proteins were identified. Analyses and functional studies of these proteins will provide novel information for better understanding of the pathogenesis of REV and the mechanisms of virus-host interactions.

\section{Materials and methods}

\section{Experimental animals and the virus strain used for infection}

All of the chickens used in this experiment were one-dayold specific-pathogen-free (SPF) White Leghorn chickens obtained from Harbin Veterinary Research Institute, Chinese Academy of Agricultural Sciences. Chickens were kept in isolators at Harbin Veterinary Research Institute throughout the experiment.

Chickens were infected with the HLJ07I strain of REVA (GenBank accession no. GQ375848), which was isolated in Heilongjiang Province of China in 2007. REV was propagated in chicken embryo fibroblast (CEF) as described previously [77].

\section{Experimental design}

Fifty-four one-day-old SPF chickens were randomly divided into two groups and were housed in isolators. One group of chickens $(\mathrm{n}=27)$ was inoculated intra-abdominally with $10^{4.6}$ tissue culture infective doses $50 \%$ $\left(\right.$ TCID $\left._{50}\right)$ of the REV-A HLJ07I strain on day 3 after hatching. The rest $(n=27)$ were kept as uninfected controls. Infected and uninfected control chickens were kept in separate isolators with similar environmental conditions. All chickens had free access to feed and water during the rearing period.

Nine chickens were selected randomly from each group and killed humanely at 7, 14, and 21 days post-inoculation. Spleens were separated rapidly and washed with ice-cold phosphate-buffered saline (PBS) buffer, snap-frozen in liquid nitrogen, and kept subsequently at $-80{ }^{\circ} \mathrm{C}$ until further processing. Animal experiments were performed in accordance with animal ethics guidelines and approved protocols. All animal studies were approved by the Animal Ethics Committee of Harbin Veterinary Research Institute of the Chinese Academy of Agricultural Sciences (SYXK (Hei) 2011022).

\section{Quantitative analysis of REV in spleen by real-time RT-PCR}

Tissue samples were ground and homogenized, $100 \mathrm{mg}$ of tissue homogenate was suspended in $500 \mu \mathrm{l}$ of PBS containing $100 \mu \mathrm{g}$ of penicillin and $100 \mu \mathrm{g}$ of streptomycin per $\mathrm{ml}$, and the suspension was frozen and thawed three times and centrifuged at $13,000 \times g$ at $4{ }^{\circ} \mathrm{C}$ for 5 minutes. RNA was extracted from $200 \mu \mathrm{l}$ of tissue supernatant using TRIzol Reagent (Invitrogen) following the manufacturer's instructions. The amount of total RNA in each sample was determined using a NanoVue Spectrophotometer. cDNA was synthesized, using AMV reverse transcriptase (TaKaRa) and $0.5 \mu \mathrm{g}$ of random primers $(\mathrm{TaKaRa})$, at $42{ }^{\circ} \mathrm{C}$ for $60 \mathrm{~min}$. The cDNA was stored at $-20{ }^{\circ} \mathrm{C}$ until it was used in the real-time PCR. The absolute REV genome load in the REV-infected spleens of chickens was quantified using primers specific for REV gag gene. The primers used are as follows: forward primer, AGACTCGCATTGTCGATGTCTTG; reverse primer, CAAATCTTTGCCAATCAA TATCAG. Linear regression analysis of the standard curve was used to estimate the number of viral genomic RNA copies per $100 \mathrm{ng}$ of spleen RNA. The standard RNA curve was linear in the range between $10^{2}$ molecules at the lower limit and $10^{9}$ molecules at the upper limit. A real-time PCR assay was performed in a total volume of $20 \mu \mathrm{l}$ containing $10 \mu \mathrm{l}$ of SYBR $^{\circledR}$ Premix Ex Taq ${ }^{\mathrm{TM}}(2 \times$; Takara, Shiga, Japan), $100 \mathrm{ng}$ of cDNA, $10 \mathrm{pmol}$ of forward primer, and $10 \mathrm{pmol}$ of reverse primer using a LightCycler ${ }^{\circledR} 480$ Real-Time PCR System (Roche Diagnostics). The PCR protocol consisted of an initial denaturation step at $95{ }^{\circ} \mathrm{C}$ for $120 \mathrm{~s}$ and 40 cycles of denaturation $\left(95^{\circ} \mathrm{C}\right.$ for $\left.15 \mathrm{~s}\right)$, annealing $\left(61{ }^{\circ} \mathrm{C}\right.$ for $\left.30 \mathrm{~s}\right)$, and extension $\left(72{ }^{\circ} \mathrm{C}\right.$ for $\left.15 \mathrm{~s}\right)$. For each step, the temperature transition rate was $20^{\circ} \mathrm{C} / \mathrm{s}$. Experiments on each sample were performed in triplicate with the above primers. The data were analyzed using LightCycler ${ }^{\circledR}$ 480 Software Version 1.5.

\section{Sample preparation for proteomic analysis}

The frozen tissues were rinsed in ice-cold PBS buffer and then placed in liquid nitrogen and ground thoroughly to a very fine powder. Tissue powder $(100 \mathrm{mg})$ was dissolved in $500 \mu \mathrm{l}$ of lysing solution containing $7 \mathrm{M}$ urea, $2 \mathrm{M}$ thiourea, 4\% CHAPS, $40 \mathrm{mM}$ DTT, 2\% IPG buffer, $\mathrm{pH}$ 
3-10 or $\mathrm{pH} 4-7,1 \%$ Nuclease Mix and 1\% Protease Inhibitor Mix (GE Healthcare, Amersham, UK), incubated for $2 \mathrm{~h}$ at room temperature with vortexing once every $15 \mathrm{~min}$, and centrifuged at $15000 \times g$ for $1 \mathrm{~h}$ at $4{ }^{\circ} \mathrm{C}$. The supernatant was collected and purified using a Plus One 2-D Clean-up kit (GE Healthcare, Amersham, UK). The concentration of each protein sample was determined using a Plus One 2-D Quant Kit (GE Healthcare). Protein samples were aliquoted and stored at $-80{ }^{\circ} \mathrm{C}$ for 2-DE analysis.

\section{Two-dimensional polyacrylamide gel electrophoresis (2D-PAGE)}

Three independent sample pools of each kind of tissue per group were used for 2-DE analysis. Each analytical 2DPAGE gel was prepared with $400 \mu \mathrm{g}$ of protein mixed with rehydration buffer (8 M urea, 2\% CHAPS, $90 \mathrm{mM}$ DTT, $5 \mu \mathrm{l}$ of the appropriate IPG buffer per ml, $12 \mu \mathrm{l}$ of DeStreak Reagent (GE Healthcare) per $\mathrm{ml}$ and $0.005 \%$ bromophenol blue) to a total volume of $250 \mu$ l. The firstdimension separation was performed in 24-cm, $\mathrm{pH} 4-7$ non-linear Immobiline DryStrips (GE Healthcare) using an Ettan IPGphor isoelectric focusing unit (GE Healthcare). After rehydration at $30 \mathrm{~V}$ for $12 \mathrm{~h}$, isoelectric focusing was performed at $500 \mathrm{~V}$ for $1 \mathrm{~h}, 1000 \mathrm{~V}$ for $1 \mathrm{~h}$ and $8000 \mathrm{~V}$ until a total of 57,000 volt hours was reached. Each focused strip was incubated at room temperature, initially in $10 \mathrm{ml}$ of equilibration buffer (50 mM Tris- $\mathrm{Cl}$ [pH 8.8], $6 \mathrm{M}$ urea, $30 \%$ [v/v] glycerol, 2\% [w/v] SDS and $0.005 \%$ bromophenol blue) containing $1 \%(\mathrm{w} / \mathrm{v})$ DTT for $15 \mathrm{~min}$ and subsequently in a similar volume of equilibration buffer containing $2.5 \%(\mathrm{w} / \mathrm{v})$ iodoacetamide for a similar time. For the second-dimension separation, each IPG strip was placed on a $12.5 \%$ SDS-polyacrylamide gel, and six such gels were simultaneously run each time subjecting each gel to $25 \mathrm{~mA}$ of current at $25^{\circ} \mathrm{C}$ in the SE600 Ruby system (GE Healthcare) until the bromophenol blue dye front reach the opposite edge of the gel. Each gel was subsequently fixed for $1 \mathrm{~h}$ in a solution containing $10 \%(\mathrm{v} / \mathrm{v})$ methanol and 7\% (v/v) acetic acid. Then, the gels were stained with PlusOne Coomassie Blue R-350 (GE Healthcare) and scanned using an Image Scanner III (GE Healthcare). Quantitative analysis was performed using Image Master 2D Platinum software v6.0 (GE Healthcare). For image analysis, three independent gels from the REVinfected group were compared with those from the corresponding control group at 7,14 , and 21 days postinfection (dpi). The normalized volume values (vol \%) of matched protein spots were subjected to Student's $t$-test using the SPSS statistical software package version 16.0. The criterion used to define differential expression of spots was that the ratio of the vol \% in the REV-infected group vs. the control group was more than $1.5(p<0.05)$ or less than $0.67(p<0.05)$. Protein spots corresponding to differentially expressed proteins were excised manually from the gels and subjected to mass spectrometry analysis.

\section{MALDI-TOF/TOF MS and database search}

Gel samples were placed in a tube and washed once with $500 \mu \mathrm{l}$ of $\mathrm{ddH}_{2} \mathrm{O}$ and once with $250 \mu \mathrm{l}$ of $\mathrm{ddH}_{2} \mathrm{O}$, each for $15 \mathrm{~min}$. For trypsin digestion, the gel samples were washed twice with $50 \mathrm{mM} \mathrm{NH} \mathrm{NCO}_{3}$ and covered with $50 \mathrm{mM}$ $\mathrm{NH}_{4} \mathrm{HCO}_{3}$ containing $10 \mathrm{mg}$ of porcine trypsin solution (Promega, Madison, WI, USA) per ml. After incubation overnight at $37{ }^{\circ} \mathrm{C}$, the supernatant was transferred to a

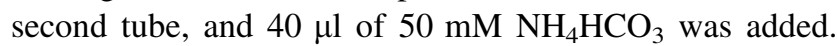
Gel samples were washed with $40 \mu \mathrm{l}$ of $50 \mathrm{mM} \mathrm{NH}_{4} \mathrm{HCO}_{3}$, and the supernatants were collected and combined. The gel was washed with $70 \% \mathrm{v} / \mathrm{v}$ acetonitrile $(\mathrm{ACN})$ and dried in a SpeedVac Vacuum Concentrator (Bachhofer). The peptide mixtures were desalted using ZipTip C-18 RP tips (Millipore, Billerica, MA, USA), which were wetted with $100 \%$ ACN and equilibrated with $0.1 \%$ trifluoroacetic acid (TFA). Peptide samples, which were redissolved in $10 \mathrm{ml}$ of $0.5 \%$ TFA, were eluted with $50 \%$ ACN $/ 0.1 \%$ TFA and dried in a SpeedVac Vacuum Concentrator.

The purified peptides were spotted on a MALDI plate and covered with $0.7 \mu \mathrm{l}$ of $2 \mathrm{mg} / \mathrm{ml} \mathrm{3,5-dimethoxy-4-hy-}$ droxycinnamic acid matrix (Sigma, St. Louis, MO, USA) with $10 \mathrm{mM} \mathrm{NH} \mathrm{NH}_{2} \mathrm{PO}_{4}$ in $60 \%$ ACN. All samples were analyzed by MALDI-TOF/TOF MS using a 4700 Proteomics Analyzer (Applied Biosystems, Foster City, CA). Monoisotopic peak masses were acquired in a mass range of 800-4000 Da, with a signal-to-noise ratio $(\mathrm{S} / \mathrm{N})$ of 200 . Five of the most intense ion signals, excluding common trypsin autolysis peaks and matrix ion signals, were selected as precursors for MS/MS acquisition. The peptide mass fingerprint (PMF) combined MS/MS data were submitted to MASCOT version 3.0 (Matrix Science) for identification according to the NCBInr database (release 16/01/2010, 10343571 sequences, 3528215794 residues). The search parameters were set as follows: Gallus, trypsin cleavage (one missed cleavage allowed), carbamidomethylation of cysteine as fixed modification, oxidation of methionine as variable modification, peptide mass tolerance set at $100 \mathrm{ppm}$, fragment tolerance set at $0.8 \mathrm{Da}$. The criterion for successful identification of a protein was a protein score confidence interval (C.I. \%) $\geq 95 \%$.

\section{Gene Ontology (GO) analysis}

Spot identities were submitted to GORetriever (http:// www.agbase.msstate.edu/) to obtain the GO annotations. If no annotation was returned, GOanna was used to retrieve GO annotations assigned based on sequence similarity. The 
resulting annotations were summarized based on the GOA and whole proteome GOSlim set using GOSlimViewer [45].

\section{Results}

\section{Determination of REV genome load in infected spleens}

Successful REV infection was verified using real-time RTPCR. The results are presented in Figure 1. Virus was not detected in the spleens of chickens in the control group. In the REV-infected group, high levels of viral RNA copies were detected in the spleen at 7,14 , and $21 \mathrm{dpi}$, indicating the development of persistent infection.

\section{Spot profiles of 2D PAGE of REV-infected and uninfected control chicken spleens}

Proteins from spleens of REV-infected and uninfected control chickens at 7,14 and $21 \mathrm{dpi}$ were extracted and analyzed by $2-\mathrm{DE}$ in order to compare the protein expression profiles of each group. Approximately 500-600 distinct protein spots could be resolved by 2-DE using $\mathrm{pH}$ 4-7NL IPG strips loaded with $400 \mu \mathrm{g}$ of total protein. The molecular weights of the proteins in the spots ranged from 12 to $105 \mathrm{kDa}$. Both qualitative and quantitative differences were seen in the protein profiles of infected and uninfected chickens (Fig. 2). Comparing multiple 2-DE gel images, we found 70 protein spots in which the proteins were differentially expressed in the infected and uninfected

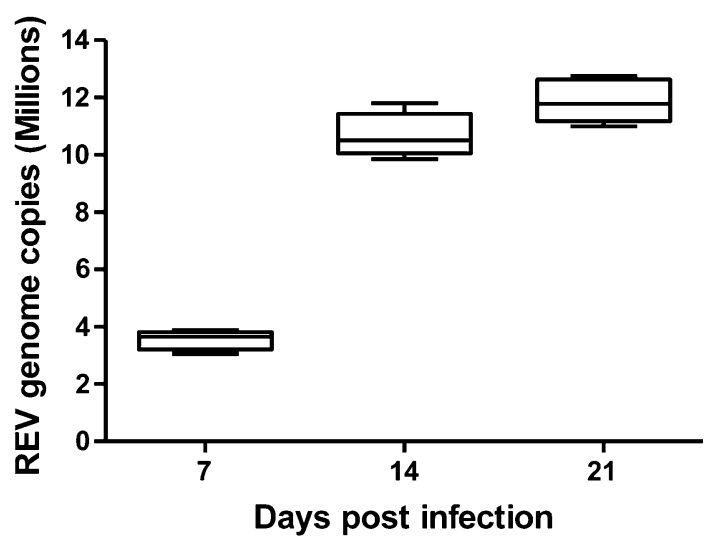

Fig. 1 REV genome load in infected spleens. Chickens were infected with the HLJ07I strain of REV and sampled at 7, 14 and 21 days postinfection. Gag copy numbers in $100 \mathrm{ng}$ of spleen RNA were quantitated using real-time RT-PCR. At least three spleen samples were analyzed in duplicate at each sampling time point. The error bars represent standard error of the mean groups at different time points. After statistical analysis, we selected 63 proteins with steady change at three time points for identification by MALDI-TOF/TOF. Sixty of them were successfully identified, including 15 that were persistently upregulated, 14 that were persistently downregulated, and 31 with fluctuating expression (Table 1 and Fig. 2).

\section{Identification of differentially expressed proteins by mass spectrometry}

In order to identify differentially expressed proteins, the spots were manually excised from preparative gels prepared by loading $400 \mu \mathrm{g}$ of total protein and staining with Coomassie blue. Subsequently, trypsin-digested spots were identified by MALDI-TOF-TOF MS. The PMF data was searched against the NCBInr database using MASCOT. In total, the identity of proteins in 60 different spots representing 28 different proteins was determined (Table 1). Moreover, several spots contained peptides generated from multiple proteins.

Several proteins were differentially expressed at more than one time point, e.g., vimentin, cognin/proly1-4-hydroxylase/protein disulfide isomerase (PDIA3), hypothetical protein, actin-cytoplasmic type 5 (ACT5), ferritin $\mathrm{H}$ subunit, annexin A6 (ANXA6), annexin A5 (ANXA5), cathepsin B (CTSB), and rho GDP-dissociation inhibitor 1 (Rho-GDI) at all three time points. In total, 14 proteins were differentially expressed exclusively at $7 \mathrm{dpi}$. There was only one spot that was specific to $21 \mathrm{dpi}$ (Fig. 3). The significant changes detected with the rest of the spots overlapped between time points to varying degrees. Differences in the pattern of change were observed predominantly in the early stages of the infection cycle, which suggests that critical events early in infection are important in determining the fate of the host.

Interestingly, some of the spots representing a particular protein showed opposite directions of regulation even within the same group. For example, three spots with different molecular weights and $\mathrm{pI}$ values were identified as hypothetical proteins (Table 1). Of these three spots, two spots with molecular weights of 53.74 and $42.10 \mathrm{kDa}$ were found to be upregulated in infected chickens at more than one time point. The summarized distribution of the identities of spots identified at each time point is presented in Figure 3.

\section{Gene Ontology annotation}

In order to gain an overview of the subcellular location and biological processes associated with proteins that 
Fig. 2 Representative 2D gel images of REV-infected and uninfected control spleen proteomes at different sampling times. The differentially expressed protein spots are shown in gels with their unique sample spot protein numbers. Arrows indicate the successfully identified protein spots. Please refer to Table 1 for the identities of the proteins in the numbered spots
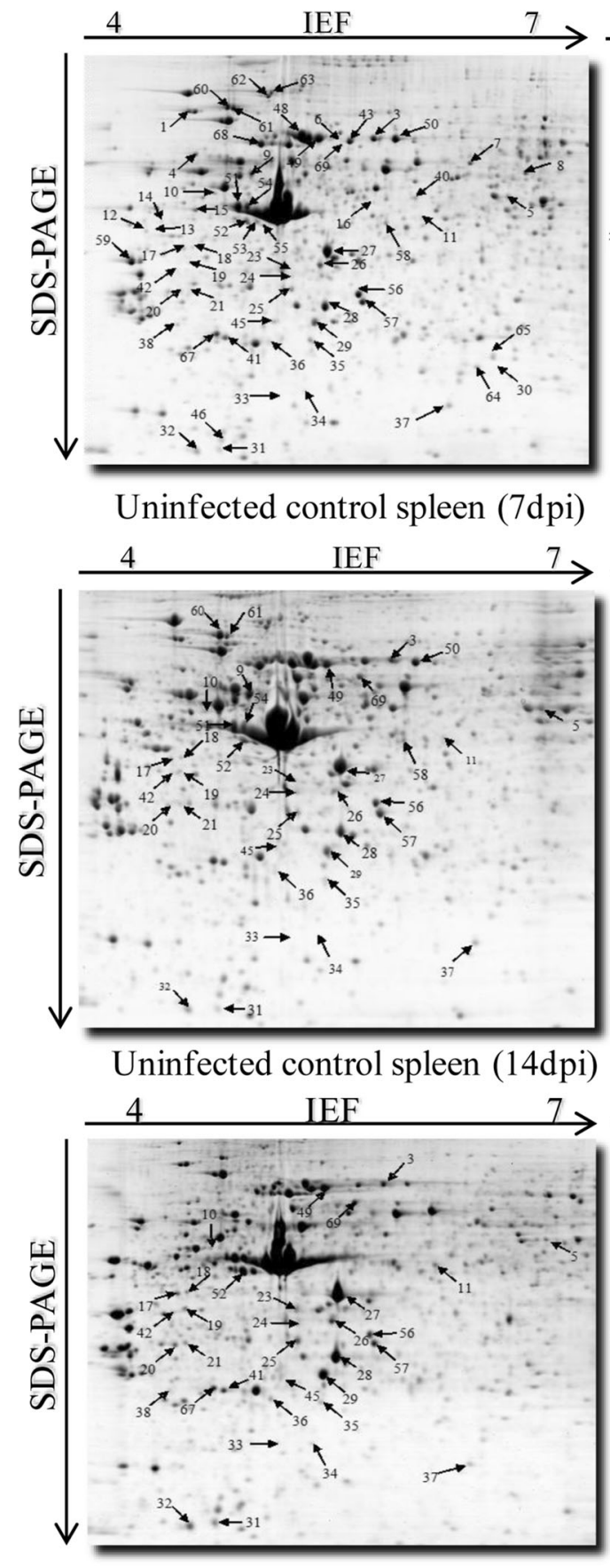

Uninfected control spleen (21dpi)

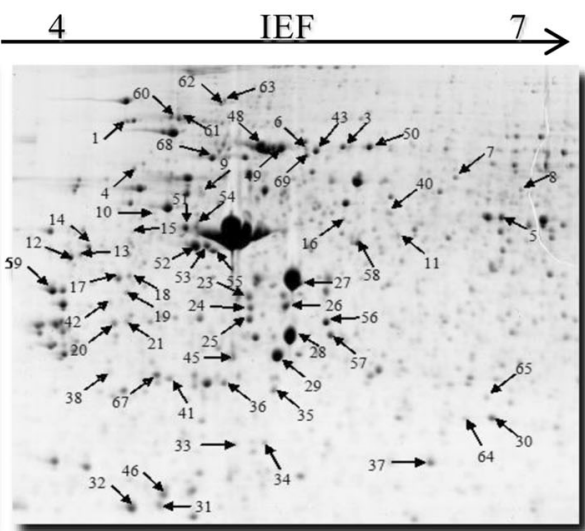

REV-infected spleen (7dpi)

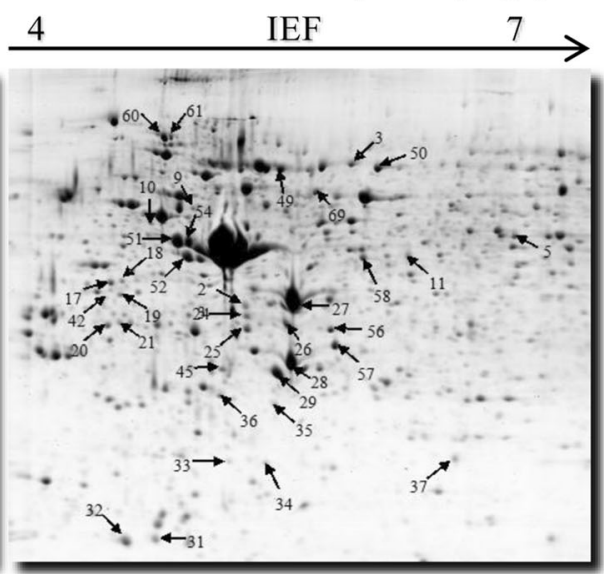

REV-infected spleen (14dpi)

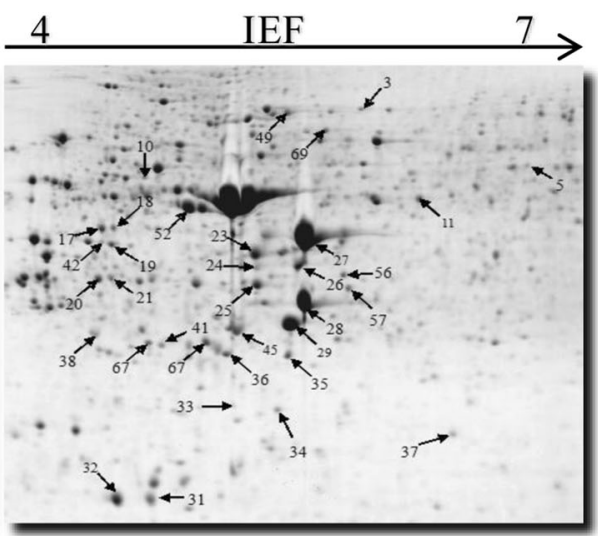

REV-infected spleen (21dpi) underwent changes in expression levels in REV-A infected spleen, categorization of these proteins was performed based on Gene Ontology (GO) annotations. As shown in Figure 4, $49 \%$ of these proteins were identified as cytoplasmic (term GO: 0005737). The most frequent associated biological process GO terms were metabolic process (GO: 0008152) and response to stimulus (GO: 0050896). These was followed by GO terms including but not limited to signal transduction, transport and antioxidant activity.

\section{Discussion}

In the present study, we have profiled the global protein expression changes in chicken spleen that occur in response to REV infection at various time points representing different phases of the REV life cycle. Furthermore, we have identified proteins that were differentially expressed between infected and uninfected birds, using mass spectrometry. 
Table 1 List of the differentially expressed proteins in spleen identified by MALDI/TOF/TOF and MS/MS analysis

\begin{tabular}{|c|c|c|c|c|c|c|}
\hline $\begin{array}{l}\text { Spot } \\
\text { ID }\end{array}$ & Protein name & $\begin{array}{l}\text { Accession } \\
\text { no. }\end{array}$ & $\begin{array}{l}\text { Fold change in } \\
\text { expression }\end{array}$ & $\begin{array}{l}\text { pI, MW } \\
(\mathrm{kDa})\end{array}$ & $\begin{array}{l}\text { Protein } \\
\text { score }\end{array}$ & Function \\
\hline
\end{tabular}

\begin{tabular}{|c|c|c|c|c|c|c|c|c|}
\hline & Cellular structural protein & & & & & & & \\
\hline 42 & Beta-actin & gil63018 & +2.0 & +1.6 & +2.3 & $5.29 / 42.07$ & 505 & Unknown \\
\hline 63 & Alpha-actinin-4 (ACTN4) & gil45384104 & -1.4 & -1.1 & $\mathrm{~N}$ & $\begin{array}{l}5.13 / \\
104.71\end{array}$ & 528 & $\begin{array}{l}\text { Actin binding calcium ion } \\
\text { binding }\end{array}$ \\
\hline 7 & Actin, cytoplasmic type 5 & gil56119084 & -2.1 & $\mathrm{~N}$ & $\mathrm{~N}$ & $5.30 / 42.15$ & 265 & ATP binding \\
\hline 17 & Actin, cytoplasmic type 5 (ACT5) & gil56119084 & +3.3 & +1.5 & +2.6 & $5.30 / 42.15$ & 235 & ATP binding \\
\hline 18 & Actin, cytoplasmic type 5 (ACT5) & gil56119084 & +2.4 & +1.4 & +3 & $5.30 / 42.15$ & 694 & ATP binding \\
\hline 20 & Actin, cytoplasmic type 5 (ACT5) & gil56119084 & +2.8 & +1.5 & +2.5 & $5.30 / 42.15$ & 735 & ATP binding \\
\hline 21 & Actin, cytoplasmic type 5 (ACT5) & gil56119084 & +1.7 & +1.4 & +1.9 & $5.30 / 42.15$ & 576 & ATP binding \\
\hline 22 & Actin, cytoplasmic type 5 (ACT5) & gil56119084 & +6.1 & +1.9 & +3.1 & $5.30 / 42.15$ & 868 & ATP binding \\
\hline 23 & Actin, cytoplasmic type 5 (ACT5) & gil56119084 & +14.9 & +5.6 & +2.3 & $5.30 / 42.15$ & 898 & ATP binding \\
\hline 24 & Actin, cytoplasmic type 5 (ACT5) & gil56119084 & +5.0 & +1.8 & +2.1 & $5.30 / 42.15$ & 715 & ATP binding \\
\hline 25 & Actin, cytoplasmic type 5 (ACT5) & gil56119084 & +3.0 & +1.2 & +2.4 & $5.30 / 42.15$ & 888 & ATP binding \\
\hline 26 & Actin, cytoplasmic type 5 (ACT5) & gil56119084 & +5.2 & +1.2 & +2.6 & $5.30 / 42.15$ & 808 & ATP binding \\
\hline 27 & Actin, cytoplasmic type 5 (ACT5) & gil56119084 & +2.2 & +1.6 & +1.8 & $5.30 / 42.15$ & 938 & ATP binding \\
\hline 28 & Actin, cytoplasmic type 5 (ACT5) & gil56119084 & +3.1 & +11.5 & +2.1 & $5.30 / 42.15$ & 781 & ATP binding \\
\hline 29 & Actin, cytoplasmic type 5 (ACT5) & gil56119084 & +3.6 & +1.6 & +1.8 & $5.30 / 42.15$ & 728 & ATP binding \\
\hline 30 & Actin, cytoplasmic type 5 (ACT5) & gil56119084 & +9.8 & $\mathrm{~N}$ & $\mathrm{~N}$ & $5.30 / 42.15$ & 100 & ATP binding \\
\hline 31 & Actin, cytoplasmic type 5 (ACT5) & gil56119084 & +2.5 & +2.1 & +2.3 & $5.30 / 42.15$ & 587 & ATP binding \\
\hline 32 & Actin, cytoplasmic type 5 (ACT5) & gil56119084 & +3.7 & +2.2 & +2.5 & $5.30 / 42.15$ & 81 & ATP binding \\
\hline 33 & Actin, cytoplasmic type 5 (ACT5) & gil56119084 & +2.0 & +1.2 & +2.1 & $5.30 / 42.15$ & 611 & ATP binding \\
\hline 34 & Actin, cytoplasmic type 5 (ACT5) & gil56119084 & +2.0 & $\mathrm{~N}$ & $\mathrm{~N}$ & $5.30 / 42.15$ & 650 & ATP binding \\
\hline 13 & Actin, cytoplasmic type 5 & gil56119084 & +3.2 & $\mathrm{~N}$ & $\mathrm{~N}$ & $5.30 / 42.15$ & 235 & ATP binding \\
\hline 36 & Actin, cytoplasmic type 5 (ACT5) & gil56119084 & +2.5 & +2.5 & +1.9 & $5.30 / 42.15$ & 741 & ATP binding \\
\hline 45 & Actin, cytoplasmic type 5 (ACT5) & gil56119084 & +8.9 & +9.4 & +4.0 & $5.30 / 42.15$ & 837 & ATP binding \\
\hline 53 & Actin, cytoplasmic type 5 (ACT5) & gil56119084 & +1.6 & +1.5 & +1.3 & $5.30 / 42.15$ & 618 & ATP binding \\
\hline 58 & Actin, cytoplasmic type 5 (ACT5) & gil56119084 & +2.2 & +2.5 & $\mathrm{~N}$ & $5.30 / 42.15$ & 523 & ATP binding \\
\hline 9 & Vimentin & gil212868 & -1.5 & -1.8 & -6.4 & $5.09 / 53.16$ & 177 & Structural molecule activity \\
\hline 12 & Vimentin & gil212868 & +5.7 & $\mathrm{~N}$ & $\mathrm{~N}$ & $5.09 / 53.16$ & 795 & Structural molecule activity \\
\hline \multirow[t]{2}{*}{55} & Lamin-B2(LMNB2) & gil45384202 & +3.3 & $\mathrm{~N}$ & $\mathrm{~N}$ & $5.31 / 68.01$ & 675 & Structural molecule activity \\
\hline & Signal transduction & & & & & & & \\
\hline 41 & $\begin{array}{l}\text { PREDICTED: similar to D4-GDP- } \\
\text { dissociation inhibitor (Rho-GDI) }\end{array}$ & gil50728568 & +1.6 & $\mathrm{~N}$ & $\mathrm{~N}$ & $5.08 / 22.92$ & 595 & $\begin{array}{l}\text { Rho GDP-dissociation } \\
\text { inhibitor activity }\end{array}$ \\
\hline \multirow[t]{2}{*}{67} & $\begin{array}{l}\text { Rho GDP-dissociation inhibitor } 1 \text { (Rho- } \\
\text { GDI) }\end{array}$ & gil53126513 & -1.6 & -1.1 & $\mathrm{~N}$ & $5.22 / 23.31$ & 124 & $\begin{array}{l}\text { Rho GDP-dissociation } \\
\text { inhibitor activity }\end{array}$ \\
\hline & $\begin{array}{l}\text { Stress-response and immune-response- } \\
\text { associated proteins }\end{array}$ & & & & & & & \\
\hline 3 & Heat shock protein Hsp70 & gil37590081 & -1.9 & -1.4 & -2.3 & $5.66 / 70.09$ & 949 & Stress response \\
\hline 6 & Heat shock cognate $71 \mathrm{kDa}$ protein (HSPA8) & gil45384370 & +3.0 & $\mathrm{~N}$ & $\mathrm{~N}$ & $5.47 / 71.01$ & 591 & Stress response \\
\hline 16 & $\begin{array}{l}60 \mathrm{kDa} \text { heat shock protein, mitochondrial } \\
\text { precursor (Hsp60) }\end{array}$ & gil61098372 & +2.0 & +2.0 & $\mathrm{~N}$ & $5.72 / 61.10$ & 695 & Chaperone \\
\hline $19^{*}$ & Heat shock cognate $71 \mathrm{kDa}$ protein & gil45384370 & +4.3 & +2.1 & +2 & $5.47 / 71.01$ & 38 & Stress response \\
\hline 43 & Stress-70 protein, mitochondrial precursor & gil57524986 & +1.4 & $\mathrm{~N}$ & +2.2 & $6.09 / 73.43$ & 68 & $\begin{array}{l}\text { Cell proliferation and } \\
\text { cellular aging }\end{array}$ \\
\hline 60 & $\begin{array}{l}\text { Heat shock protein HSP 90-alpha } \\
\text { (Hsp90AA1) }\end{array}$ & gil157954047 & -3.3 & -1.9 & $\mathrm{~N}$ & $5.01 / 84.40$ & 370 & $\begin{array}{l}\text { ATP binding response to } \\
\text { stress }\end{array}$ \\
\hline 61 & $\begin{array}{l}\text { Heat shock protein HSP 90-alpha } \\
\text { (Hsp90AA1) }\end{array}$ & gil157954047 & -1.4 & -1.8 & $\mathrm{~N}$ & $5.01 / 84.40$ & 544 & $\begin{array}{l}\text { ATP binding response to } \\
\text { stress }\end{array}$ \\
\hline 10 & $\begin{array}{l}\text { Cognin/prolyl-4-hydroxylase/protein } \\
\text { disulfide isomerase(PDIA3) }\end{array}$ & gil21703694 & +2.9 & +1.2 & +1.6 & $4.75 / 58.89$ & 477 & Catalytic activity \\
\hline \multirow[t]{2}{*}{40} & $\begin{array}{l}\text { Protein disulfide-isomerase A3 precursor } \\
\text { (PDIA3) }\end{array}$ & gil45383890 & +1.8 & $\mathrm{~N}$ & $\mathrm{~N}$ & $5.76 / 56.54$ & 515 & $\begin{array}{l}\text { Protein disulfide } \\
\text { oxidoreductase activity }\end{array}$ \\
\hline & Calcium ion binding & & & & & & & \\
\hline
\end{tabular}


Table 1 continued

\begin{tabular}{|c|c|c|c|c|c|c|c|c|}
\hline \multirow[t]{2}{*}{$\begin{array}{l}\text { Spot } \\
\text { ID }\end{array}$} & \multirow[t]{2}{*}{ Protein name } & \multirow[t]{2}{*}{$\begin{array}{l}\text { Accession } \\
\text { no. }\end{array}$} & \multicolumn{3}{|c|}{$\begin{array}{l}\text { Fold change in } \\
\text { expression }\end{array}$} & \multirow[t]{2}{*}{$\begin{array}{l}\text { pI, MW } \\
\text { (kDa) }\end{array}$} & \multirow[t]{2}{*}{$\begin{array}{l}\text { Protein } \\
\text { score }\end{array}$} & \multirow[t]{2}{*}{ Function } \\
\hline & & & 7 dpi & $14 \mathrm{dpi}$ & $21 \mathrm{dpi}$ & & & \\
\hline $2 *$ & Parvalbumin (pvalb1) & gil225877920 & +2.7 & $\mathrm{~N}$ & $\mathrm{~N}$ & $4.94 / 12.06$ & 44 & Calcium ion binding \\
\hline 50 & Annexin A6 (ANXA6) & gil50982399 & -2.1 & -1.4 & -2.1 & $5.57 / 75.57$ & 180 & Calcium ion binding \\
\hline 56 & $\begin{array}{l}\text { Chain A, Crystal Structures Of Chicken } \\
\text { Annexin V } \\
\text { Apoptosis or tumor-associated proteins }\end{array}$ & gil62738641 & -1.6 & -1.4 & -1.7 & $5.61 / 36.15$ & 680 & Calcium ion binding \\
\hline 15 & Serpin B6 (SERPINB6) & gil57530448 & +2.3 & $\mathrm{~N}$ & $\mathrm{~N}$ & $5.28 / 43.24$ & 397 & $\begin{array}{l}\text { Serine-type endopeptidase } \\
\text { inhibitor activity }\end{array}$ \\
\hline 70 & Cathepsin B (CTSB) & gil603203 & +2.0 & +1.4 & +1.3 & $5.74 / 38.47$ & 144 & $\begin{array}{l}\text { Regulation of catalytic } \\
\text { activity }\end{array}$ \\
\hline 62 & Valosin containing protein & gil90990971 & -4.0 & $\mathrm{~N}$ & -1.48 & $5.14 / 89.95$ & 636 & $\begin{array}{l}\text { Nucleoside-triphosphatase } \\
\text { activity }\end{array}$ \\
\hline 37 & $\begin{array}{l}\text { Ferritin H subunit } \\
\text { Other }\end{array}$ & gil21177 & +2.3 & +6.6 & +1.3 & $5.78 / 21.24$ & 493 & Ferroxidase activity \\
\hline 1 & Gamma-glutamyltransferase (TGL2) & gil62903517 & -2.7 & $\mathrm{~N}$ & $\mathrm{~N}$ & $4.90 / 79.11$ & 875 & $\begin{array}{l}\text { Gamma-glutamyltransferase } \\
\text { activity }\end{array}$ \\
\hline 5 & Argininosuccinate synthase(ASS1) & gil61657937 & +2.1 & +1.4 & $\mathrm{~N}$ & $6.10 / 47.33$ & 872 & $\begin{array}{l}\text { Arginine succinate } \\
\text { synthetase activity }\end{array}$ \\
\hline 8 & Pre-mRNA-processing factor 19 (PRPF19) & gil 86129600 & -1.9 & $\mathrm{~N}$ & $\mathrm{~N}$ & $6.19 / 55.55$ & 394 & $\begin{array}{l}\text { DNA binding } \\
\text { DNA repair }\end{array}$ \\
\hline 14 & $\begin{array}{l}\text { PREDICTED: ribosomal protein SA isoform } \\
\text { 1(RPSA) }\end{array}$ & gil118086026 & +3.8 & $\mathrm{~N}$ & $\mathrm{~N}$ & $4.8 / 33.11$ & 211 & $\begin{array}{l}\text { Laminin receptor } \\
\text { Activity(Rattus } \\
\text { norvegicus) }\end{array}$ \\
\hline $48^{*}$ & Otokeratin & gil3746660 & +1.7 & $\mathrm{~N}$ & $\mathrm{~N}$ & $5.97 / 53.77$ & 56 & Structural molecule activity \\
\hline 49 & Serum albumin precursor (VTDB) & gil45383974 & -1.3 & $\mathrm{~N}$ & -2.8 & $5.51 / 71.86$ & 341 & Vitamin transporter activity \\
\hline 57 & $\begin{array}{l}\text { Chain B, Solution Nmr Structure Of V-1 } \\
\text { Bound To Capping Protein }\end{array}$ & gil297787504 & -1.7 & $\mathrm{~N}$ & -1.4 & $5.5 / 30.71$ & 457 & Actin binding \\
\hline 59 & Alpha-tropomyosin (smooth muscle) & gil212807 & +1.6 & $\mathrm{~N}$ & +4.9 & $4.68 / 32.89$ & 292 & Actin binding \\
\hline 65 & $\begin{array}{l}\text { Similar to MGC } 84496 \text { protein } \\
\text { Hypothetical proteins }\end{array}$ & gil118101652 & -1.5 & -1.4 & -2.3 & $6.07 / 22.80$ & 176 & Unknown \\
\hline 4 & PREDICTED: hypothetical protein, partial & gil118105147 & +1.1 & +1.7 & +1.4 & $4.77 / 66.11$ & 147 & Unknown \\
\hline 11 & Hypothetical protein & gil53136508 & +2.0 & +1.2 & +1.9 & $6.22 / 53.74$ & 257 & Unknown \\
\hline 38 & Hypothetical protein & gil53126859 & +13.8 & +7.2 & +6.0 & $5.31 / 42.10$ & 535 & Unknown \\
\hline 35 & Hypothetical protein & gil53126859 & +4.1 & +3 & +2.9 & $5.31 / 42.10$ & 650 & ATP binding \\
\hline 51 & Hypothetical protein & gil53126859 & -1.2 & -1.4 & -1.2 & $5.31 / 42.10$ & 852 & Uknown \\
\hline 52 & Hypothetical protein & gil53126859 & +2.6 & +1.3 & +1.7 & $5.31 / 42.10$ & 881 & Unknown \\
\hline 54 & Hypothetical protein & gil53126859 & -2.0 & -2.5 & -1.6 & $5.31 / 42.10$ & 676 & Unknown \\
\hline 69 & Hypothetical protein & gil60098585 & -1.8 & -1.2 & -1.6 & $5.53 / 60.19$ & 850 & Chaperone ATP binding \\
\hline
\end{tabular}

a) Spot ID is the unique number that refers to the labels in Figure 3

b) Accession number: gi number in NCBI

c) Score: protein score based only on MS spectra by MALDI-TOF. Other spots were based on combined MS and MS/MS spectra from MALDITOF-TOF identification. A protein score greater than 83 is significant in this study $(P<0.05)$

“-”, downregulated protein; “+” upregulated protein; “N”, no difference; “*”, failed identification

Among the 28 proteins that were differentially expressed, there was a considerable number of proteins that produced multiple spots in $2 \mathrm{D}$ gels. In addition, there was some degree of disagreement between the expected and experimental molecular weights for some of the proteins. There could be several reasons for this. First, some proteins exist as different isoforms (and therefore have different pI values) as well as different intermediate stages between translation and attainment of the functionally mature form (i.e., pre-pro- and pro-forms of the protein). This could change the molecular weight and/or the isoelectric point as discussed below. Another reason is possible protein degradation between sample collection and processing. 
Analysis of the virus load revealed high levels of viral RNA copies in spleen tissue at 7, 14, and $21 \mathrm{dpi}$, indicating the development of persistent infection. The virus load reflects the status of viral replication and disease evolution, and it has therefore been used as an important marker for disease progression of retroviral infections $[57,74]$. Thus, it is conceivable that the virus copy numbers observed in the present study would be indicative of a high level of infection.

The proteins identified in the present study are involved in a variety of cellular processes, notably, formation of the cytoskeleton, cellular metabolism, response to stimulus, signal transduction, transport and antioxidant activity. The significance of these processes in chicken-REV interactions is discussed below. Although not determined in the present study, temporal changes in the cellular composition of the spleen may have, at least in part, influenced the organ proteome of the whole spleen. However, the advantage of our method is that the proteins that are differentially expressed could be used to point to cell subsets and/or mechanisms that have a potential involvement in REV-host interactions and could be targeted for future studies.

\section{Alterations of cytoskeletal proteins after REV-A infection}

Cytoskeletal proteins play important roles in maintaining cell morphology, regulating the progress of gene transcription and protein synthesis, and are closely related to intracellular transport and cell division [46]. It has been shown recently that various viruses manipulate and utilize the host cytoskeleton to promote viral infection [56]. Changes in cytoskeleton proteins have been described previously in infections with several other virus, such as infectious bursal disease virus (IBDV) [81], severe acute respiratory syndrome (SARS)-associated coronavirus [36], and human papillomavirus type 8 [2]. In the current study, altered spot profiles were observed for a number of cytoskeleton-associated proteins representing two main categories of cytoskeleton proteins, namely microfilaments and intermediate filaments. Among the microfilament proteins, all detected actin spots, except for alpha-actinin-4 (ACTN4), were significantly upregulated across the experimental period. Intermediate filament, lamin B2 (LMNB2) spots were also upregulated in infected birds at 7 dpi.

Actin, one of the most highly conserved proteins in eukaryotic cells, forms microfilaments, which are one of the three main components of the cytoskeleton. The role of the actin cytoskeleton in virus-induced signaling has been increasingly recognized because it is believed to act as a regulator in gene transcription [46] and might facilitate the efficient spread of progeny virus particles $[16,73]$. Actin might also participate in endocytosis, with actin rearrangements contributing to the internalization of virus particles [54]. It has been reported that expression of actin, cytoplasmic type 5(ACT5), a third cytoplasmic isoform of the chicken non-muscle actin [6], is induced in the late stages of IBDV infection [81]. In this study, chickens infected with REV showed high levels of ACT5 at 7, 14 and $21 \mathrm{dpi}$, demonstrating that ACT5 may play important roles in REV infection and proliferation.

Another component of the cytoskeleton that displays considerable alteration in chickens infected with REV is lamin B2, which forms intermediate filaments. In birds, three structurally distinct lamin isotypes have been identified according to the homologies of their amino acid sequences [69] and their protein chemical properties [40, 62]; they have been designated as lamins A, B1, and B2. Lamin B2 is the quantitatively predominant B-type lamin in chickens [30]. Previous studies have suggested that lamin is essential for DNA replication [13]. Therefore, upregulation of lamin-B2 at $7 \mathrm{dpi}$ would be beneficial for REV replication.

Viruses require cytoskeletal proteins for viral entry and establishment of infection [49], and the disruption of vimentin might block virion assembly and budding $[34,72]$. Several studies have shown that human immunodeficiency virus (HIV) type 1 protease cleaves the intermediate filament protein vimentin and induces the collapse of vimentin in infected cells $[34,60]$. We found that vimentin was downregulated. Further studies are required to determine whether REV uses an HIV-like strategy to cleave vimentin, resulting in highly decreased expression and the collapse of the vimentin network.

Herpesviruses are known to interact with the actin filament system and its regulatory protein, Rho GTPase, at various stages of infection [21]. Cumulative evidence also shows that the GTPases of the Rho family are key regulatory molecules of the actin cytoskeleton [29]. Rho-GDPdissociation inhibitor 1 (Rho-GDI) has also been reported to be member of the family of Rho-GTPase regulators, which regulate a wide variety of cellular functions by binding and inhibiting Rho GTPases [68]. Thus, it is hypothesized that downregulation of Rho-GDI during REV infection may interfere with GTPase activity.

\section{Apoptosis or tumor-associated proteins}

Cathepsin B (CathB), a cysteine proteases commonly found in lysosomes, was among the proteins that were differentially expressed in infected spleens at all three time points. The functions of cathepsin B have been linked to cell proliferation, cell differentiation, organogenesis, metabolic processes, and progression of various human tumors [79]. Various studies have suggested that cathepsin 
Fig. 3 Venn diagram summarizing the spots that were significantly differentially expressed in the spleen tissues of REV-infected chickens according to their corresponding time of sampling. The identities of spots that were commonly expressed were placed in overlapping areas accordingly. The corresponding spot numbers are shown in parentheses. Refer to Table 1 for the respective protein names

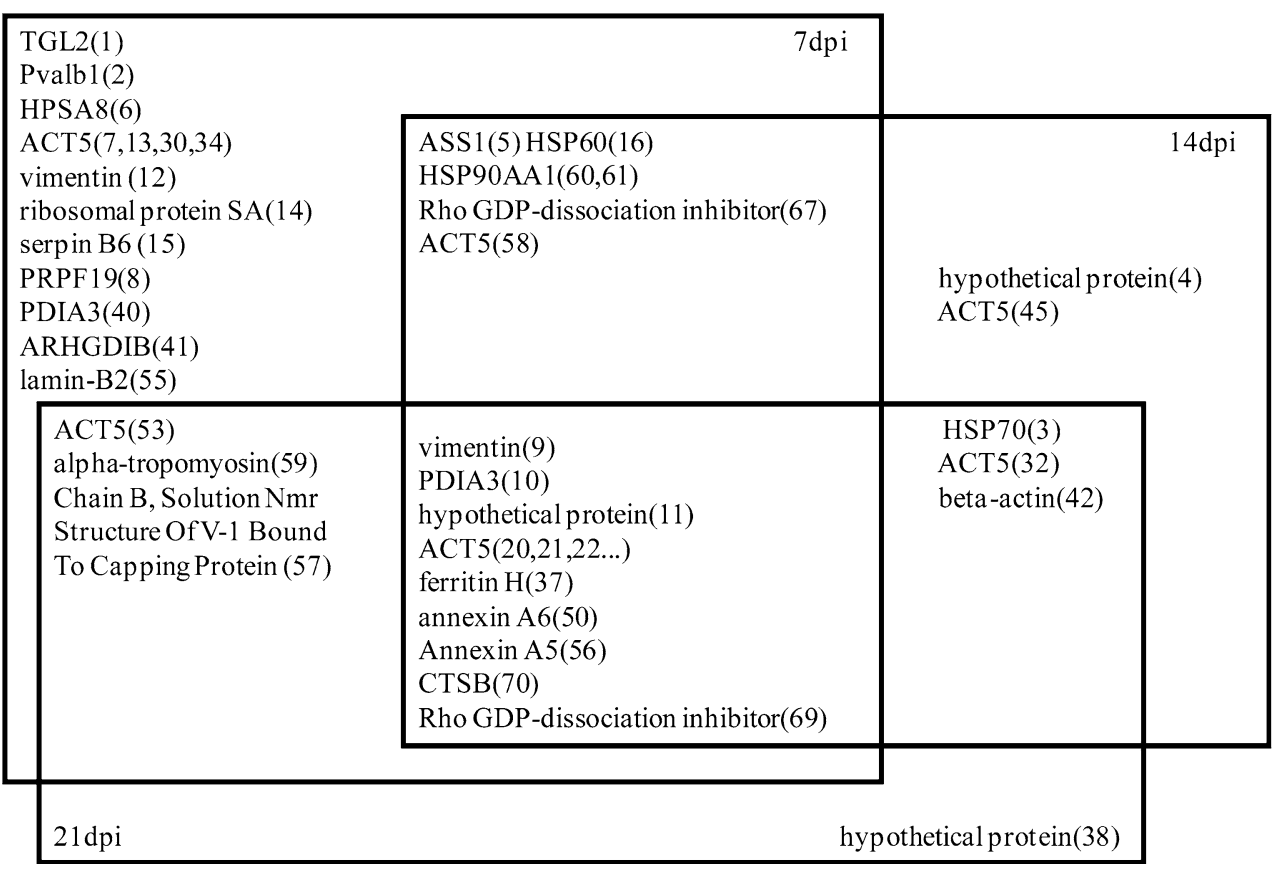

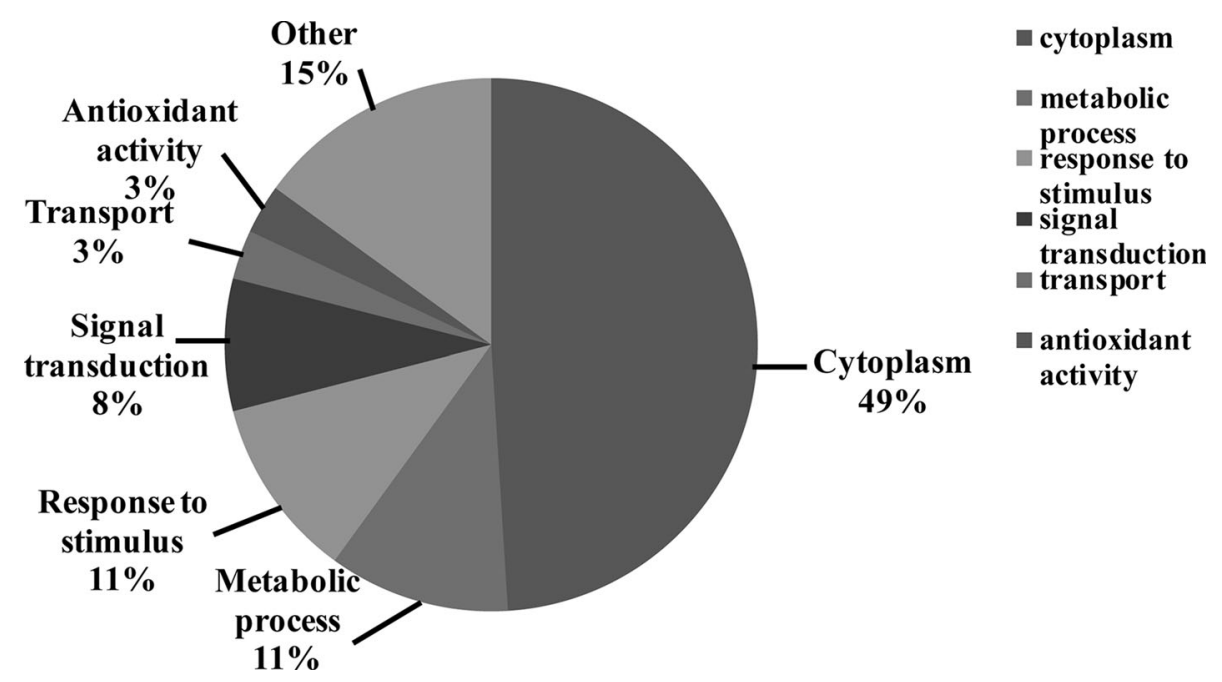

Fig. 4 Gene Ontology analysis of significantly changed proteins according to their biological process. This classification was produced based on the analysis using the GOSlimViewer tool at the Agbase database (http://www. agbase.msstate.edu/) as described in Materials and methods
B participates in the pathology of carcinomas, and it is present at increased levels in advanced tumor stages $[19,61]$. Therefore, it is conceivable that upregulated CathB may play a role in tumor formation after REV infection; however, this needs to be studied further.

The annexins are a family of $\mathrm{Ca}^{2+}$ - and phospholipidbinding proteins that interact with membranes when there is an increase in the $\mathrm{Ca}^{2+}$ concentration or during cytoplasmic acidification [8]. Annexin A5 represents a typical member of this protein family and is an important modulator of the immune response against apoptotic cells, necrotic cells, and certain viruses [48]. Annexin A6 (AnxA6) is also a member of this protein family that have been implicated in an array of physiological processes such as cell proliferation, differentiation, and signal transduction
$[25,27]$. In this study, the abundance of annexin A5 and annexin A6 was shown to be decreased at 7, 14 and 21 dpi, which suggests that those proteins may play special roles during REV infection or replication.

Members of the serpin superfamily are protease inhibitors and are associated with cell death/apoptosis and protect cells from protease-mediated cell injury and death by inhibiting the activation of serine proteases [5, 44]. Serpin B6, which is largely involved in immunity, is an intracellular serpin expressed primarily in myeloid cells, platelets, endothelial and epithelial cells [59]. It has been reported that serpin B6 plays an important role in HIV replication [82]. The high expression levels of serpin B6 in REVinfected chickens may be relevant to the reticuloendotheliosis caused by REV. 
Ferritin is a 24-subunit protein composed of two subunit types, termed $\mathrm{H}$ and $\mathrm{L}$. The ferritin $\mathrm{H}$ subunit has a potent ferroxidase activity that catalyses the oxidation of ferrous iron, whereas ferritin L plays a role in iron nucleation and protein stability [52]. Ferritin plays a role in protecting endothelial cells [3] and tumor cells [10] from oxidant damage. Increasing ferritin levels always accompany or closely precede rapid disease progression in HIV-infected patients [20]. In this study, chickens infected with REV showed high levels of ferritin at 7, 14 and $21 \mathrm{dpi}$, which may indicate advanced or progressive disease.

\section{Stress-response- and immune-response-associated proteins}

Heat-shock proteins (HSPs), which are expressed constitutively in all cells, are essential for several important cellular processes, such as protein folding, protection of proteins from denaturation or aggregation, facilitation of protein transport, and stimulation of innate and adaptive immune responses [71]. Several stress proteins have been shown to play roles in the life cycle of a variety of RNA and DNA viruses [58]. In this study, four HSPs were differentially expressed during REV infection. One was HSP60, a highly conserved stress protein that has chaperone functions in regulating apoptosis [26] and eliciting a potent proinflammatory response in cells of the innate immune system [51]. Two others were HSP70 and HSC70, which are involved in apoptosis regulation, signal transduction and eliciting cancer immunity [4, 18, 67]. Hsp70 induction serves to signal to the immune system the presence of an immunologically relevant (dangerous) situation against which an immune reaction should be raised [65]. Both the stress-inducible protein Hsp70 and its constitutive form Hsc70 interact with various viral proteins and may be involved in the assembly of adenovirus, enterovirus and polyomavirus capsid protein complexes [15, 42, 43]. Hsp70 expression is selectively increased following infection with HIV-1 [70], and it has been suggested that Hsp70 plays a role in the nuclear import of HIV-1 preintegration complexes [1] and early events of infection [28]. The fourth HSP was HSP90, the expression of which was reduced in REV-infected chickens at 7 and 14 dpi. Hsp60, Hsp70, and Hsp90 have been shown to interact with hepatitis $B$ virus reverse transcriptase and to facilitate the initiation of viral DNA synthesis from hepatitis B virus pregenomic RNA [35, 53]. Significant changes in the expression of HSP70 and HSP90 in the spleen of MDVinfected birds has been reported [64]. In line with that, we also observed downregulated expression of HSP90 proteins in REV-infected chickens. However, the possible effects of HSP90 on immune suppression caused by REV needs to be explored in future studies.
Protein disulfide isomerase A3 (PDIA3) is a member of the endoplasmic reticulum stress signaling pathway and is associated with malignant stages of prostate cancer [50, 55]. In addition to its role in the ER stress pathway, PDIA3 is a part of the major histocompatibility complex (MHC) class I peptide-loading complex, which is essential for the formation of the final antigen conformation and for export from the endoplasmic reticulum to the cell surface [24]. In PDIA3-deficient mice, this complex is impaired and negatively influences presentation of antigenic peptides. This may help tumors to escape from immune surveillance by cytotoxic $\mathrm{T}$ cells [23]. PDIA3 aides in dengue virus (DENV) replication by suppressing TNF- $\alpha$ production in human monocytic THP1 cells [47]. Our previous studies showed that TNF- $\alpha$ was also downregulated in REV-infected chickens [78]. Thus, the upregulation of PDIA3 may relevant to tumor formation and contribute to REV-A replication.

\section{Hypothetical proteins}

Hypothetical proteins are predicted proteins that do not have experimental evidence for their translation nor do they have a characterized function [22]. In this study, hypothetical protein RCJMB04_1h13 with ID gil53126859 was highly increased at 7, 14 and $21 \mathrm{dpi}$. As reported by Caldwell et al., the most frequent molecular function associated with a domain is 'ATP binding', assigned to protein kinase domains and other domains such as the AAA ATPase family, ABC transporters and others [9]. The upregulation of hypothetical proteins is similar to that of actin in this study, which demonstrates that they may play important roles in REV infection and proliferation.

In conclusion, the findings of the present study highlight some of the mechanisms involved in the host response in the spleen to REV infection at various time points representing different stages of REV pathogenesis. Although the functions of the proteins that were identified here were not studied, it is likely that all or some of them are involved in host-virus interactions. One of the limitations of the tools used in this study is the inefficiency of detecting low-abundance proteins or those with low molecular weights, such as cytokines and chemokines. Therefore, a more comprehensive study is needed to elaborate on our present observations and to further explore other proteins that may play a role in the pathogenesis of and host responses to this virus.

Acknowledgements This study was supported by a grant from the National Natural Science Foundation of China (31302092).

\section{Compliance with ethical standards}

Conflict of interest All authors declare that they have no conflict of interest. 
Ethical approval All animal studies were approved by the Animal Ethics Committee of Harbin Veterinary Research Institute of the Chinese Academy of Agricultural Sciences (SYXK (Hei) 2011022).

Open Access This article is distributed under the terms of the Creative Commons Attribution 4.0 International License (http://crea tivecommons.org/licenses/by/4.0/), which permits unrestricted use, distribution, and reproduction in any medium, provided you give appropriate credit to the original author(s) and the source, provide a link to the Creative Commons license, and indicate if changes were made.

\section{References}

1. Agostini I, Popov S, Li J, Dubrovsky L, Hao T, Bukrinsky M (2000) Heat-shock protein 70 can replace viral protein R of HIV1 during nuclear import of the viral preintegration complex. Exp Cell Res 259:398-403

2. Akgul B, Zigrino P, Frith D, Hanrahan S, Storey A (2009) Proteomic analysis reveals the actin cytoskeleton as cellular target for the human papillomavirus type 8. Virology 386:1-5

3. Balla G, Jacob HS, Balla J, Rosenberg M, Nath K, Apple F, Eaton JW, Vercellotti GM (1992) Ferritin: a cytoprotective antioxidant strategem of endothelium. J Biol Chem 267:18148-18153

4. Beere HM, Wolf BB, Cain K, Mosser DD, Mahboubi A, Kuwana T, Tailor P, Morimoto RI, Cohen GM, Green DR (2000) Heatshock protein 70 inhibits apoptosis by preventing recruitment of procaspase-9 to the Apaf-1 apoptosome. Nat Cell Biol 2:469-475

5. Benarafa C, Remold-O'Donnell E (2005) The ovalbumin serpins revisited: perspective from the chicken genome of clade B serpin evolution in vertebrates. Proc Natl Acad Sci USA 102:11367-11372

6. Bergsma DJ, Chang KS, Schwartz RJ (1985) Novel chicken actin gene: third cytoplasmic isoform. Mol Cell Biol 5:1151-1162

7. Bohls RL, Linares JA, Gross SL, Ferro PJ, Silvy NJ, Collisson EW (2006) Phylogenetic analyses indicate little variation among reticuloendotheliosis viruses infecting avian species, including the endangered Attwater's prairie chicken. Virus Res 119:187-194

8. Burgoyne RD, Geisow MJ (1989) The annexin family of calcium-binding proteins. Review article. Cell Calcium 10:1-10

9. Caldwell RB, Kierzek AM, Arakawa H, Bezzubov Y, Zaim J, Fiedler P, Kutter S, Blagodatski A, Kostovska D, Koter M, Plachy J, Carninci P, Hayashizaki Y, Buerstedde JM (2005) Fulllength cDNAs from chicken bursal lymphocytes to facilitate gene function analysis. Genome Biol 6:R6

10. Cermak J, Balla J, Jacob HS, Balla G, Enright H, Nath K, Vercellotti GM (1993) Tumor cell heme uptake induces ferritin synthesis resulting in altered oxidant sensitivity: possible role in chemotherapy efficacy. Cancer Res 53:5308-5313

11. Chen PY, Cui Z, Lee LF, Witter RL (1987) Serologic differences among nondefective reticuloendotheliosis viruses. Arch Virol 93:233-245

12. Coffin JM (1996) Retrovirus restriction revealed. Nature 382:762-763

13. Cohen M, Lee KK, Wilson KL, Gruenbaum Y (2001) Transcriptional repression, apoptosis, human disease and the functional evolution of the nuclear lamina. Trends Biochem Sci 26:41-47

14. Cook MK (1969) Cultivation of a filterable agent associated with Marek's disease. J Natl Cancer Inst 43:203-212

15. Cripe TP, Delos SE, Estes PA, Garcea RL (1995) In vivo and in vitro association of hsc70 with polyomavirus capsid proteins. J Virol 69:7807-7813
16. Cudmore S, Cossart P, Griffiths G, Way M (1995) Actin-based motility of vaccinia virus. Nature 378:636-638

17. Cui Z, Sun S, Zhang Z, Meng S (2009) Simultaneous endemic infections with subgroup $\mathrm{J}$ avian leukosis virus and reticuloendotheliosis virus in commercial and local breeds of chickens. Avian Pathol 38:443-448

18. Dybdahl B, Wahba A, Lien E, Flo TH, Waage A, Qureshi N, Sellevold OF, Espevik T, Sundan A (2002) Inflammatory response after open heart surgery: release of heat-shock protein 70 and signaling through toll-like receptor-4. Circulation 105:685-690

19. Ebert MP, Kruger S, Fogeron ML, Lamer S, Chen J, Pross M, Schulz HU, Lage H, Heim S, Roessner A, Malfertheiner P, Rocken C (2005) Overexpression of cathepsin B in gastric cancer identified by proteome analysis. Proteomics 5:1693-1704

20. Ellaurie M, Rubinstein A (1994) Ferritin levels in pediatric HIV1 infection. Acta Paediatr 83:1035-1037

21. Favoreel HW, Enquist LW, Feierbach B (2007) Actin and Rho GTPases in herpesvirus biology. Trends Microbiol 15:426-433

22. Galperin MY, Koonin EV (2004) 'Conserved hypothetical' proteins: prioritization of targets for experimental study. Nucleic Acids Res 32:5452-5463

23. Garbi N, Tanaka S, Momburg F, Hammerling GJ (2006) Impaired assembly of the major histocompatibility complex class I peptideloading complex in mice deficient in the oxidoreductase ERp57. Nat Immunol 7:93-102

24. Garbi N, Hammerling G, Tanaka S (2007) Interaction of ERp57 and tapasin in the generation of MHC class I-peptide complexes. Curr Opin Immunol 19:99-105

25. Gerke V, Creutz CE, Moss SE (2005) Annexins: linking $\mathrm{Ca}_{2}+$ signalling to membrane dynamics. Nat Rev Mol Cell Biol 6:449-461

26. Goh YC, Yap CT, Huang BH, Cronshaw AD, Leung BP, Lai PB, Hart SP, Dransfield I, Ross JA (2011) Heat-shock protein 60 translocates to the surface of apoptotic cells and differentiated megakaryocytes and stimulates phagocytosis. Cell Mol Life Sci 68:1581-1592

27. Grewal T, Enrich C (2006) Molecular mechanisms involved in Ras inactivation: the annexin A6-p120GAP complex. Bioessays 28:1211-1220

28. Gurer C, Cimarelli A, Luban J (2002) Specific incorporation of heat shock protein 70 family members into primate lentiviral virions. J Virol 76:4666-4670

29. Hall A (1998) Rho GTPases and the actin cytoskeleton. Science 279:509-514

30. Heitlinger E, Peter M, Haner M, Lustig A, Aebi U, Nigg EA (1991) Expression of chicken lamin B2 in Escherichia coli: characterization of its structure, assembly, and molecular interactions. J Cell Biol 113:485-495

31. Hertig C, Coupar BE, Gould AR, Boyle DB (1997) Field and vaccine strains of fowlpox virus carry integrated sequences from the avian retrovirus, reticuloendotheliosis virus. Virology 235:367-376

32. Hoelzer JD, Franklin RB, Bose HR Jr (1979) Transformation by reticuloendotheliosis virus: development of a focus assay and isolation of a nontransforming virus. Virology 93:20-30

33. Hoelzer JD, Lewis RB, Wasmuth CR, Bose HR Jr (1980) Hematopoietic cell transformation by reticuloendotheliosis virus: characterization of the genetic defect. Virology 100:462-474

34. Honer B, Shoeman RL, Traub P (1991) Human immunodeficiency virus type 1 protease microinjected into cultured human skin fibroblasts cleaves vimentin and affects cytoskeletal and nuclear architecture. J Cell Sci 100(Pt 4):799-807

35. Hu J, Seeger C (1996) Hsp90 is required for the activity of a hepatitis B virus reverse transcriptase. Proc Natl Acad Sci USA 93:1060-1064 
36. Jiang XS, Tang LY, Dai J, Zhou H, Li SJ, Xia QC, Wu JR, Zeng $R$ (2005) Quantitative analysis of severe acute respiratory syndrome (SARS)-associated coronavirus-infected cells using proteomic approaches: implications for cellular responses to virus infection. Mol Cell Proteomics 4:902-913

37. Jones D, Brunovskis P, Witter R, Kung HJ (1996) Retroviral insertional activation in a herpesvirus: transcriptional activation of US genes by an integrated long terminal repeat in a Marek's disease virus clone. J Virol 70:2460-2467

38. Kawamura $\mathrm{H}$, Wakabayashi $\mathrm{T}$, Yamaguchi $\mathrm{S}$, Taniguchi $\mathrm{T}$, Takayanagi N (1976) Inoculation experiment of Marek's disease vaccine contaminated with a reticuloendotheliosis virus. Natl Inst Anim Health Q (Tokyo) 16:135-140

39. Lang MC, Cansier C, Rizza P, Jasmin C, Tovey MG, Eid P (1997) Comparative study of the expression of cellular proteins in uninfected and HIV infected U937 cells using two dimensional SDS polyacrylamide gel electrophoresis. Chem Biol Interact 103:179-186

40. Lehner CF, Kurer V, Eppenberger HM, Nigg EA (1986) The nuclear lamin protein family in higher vertebrates. Identification of quantitatively minor lamin proteins by monoclonal antibodies. J Biol Chem 261:13293-13301

41. Ludford CG, Purchase HG, Cox HW (1972) Duck infectious anemia virus associated with Plasmodium lophurae. Exp Parasitol 31:29-38

42. Macejak DG, Luftig RB (1991) Association of HSP70 with the adenovirus type 5 fiber protein in infected HEp-2 cells. Virology 180:120-125

43. Macejak DG, Sarnow P (1992) Association of heat shock protein 70 with enterovirus capsid precursor P1 in infected human cells. J Virol 66:1520-1527

44. Mangan MS, Kaiserman D, Bird PI (2008) The role of serpins in vertebrate immunity. Tissue Antigens 72:1-10

45. McCarthy FM, Bridges SM, Wang N, Magee GB, Williams WP, Luthe DS, Burgess SC (2007) AgBase: a unified resource for functional analysis in agriculture. Nucleic Acids Res 35:D599-D603

46. Miralles F, Visa N (2006) Actin in transcription and transcription regulation. Curr Opin Cell Biol 18:261-266

47. Mishra KP, Shweta Diwaker D, Ganju L (2012) Dengue virus infection induces upregulation of hn RNP-H and PDIA3 for its multiplication in the host cell. Virus Res 163:573-579

48. Munoz LE, Frey B, Pausch F, Baum W, Mueller RB, Brachvogel B, Poschl E, Rodel F, von der Mark K, Herrmann M, Gaipl US (2007) The role of annexin A5 in the modulation of the immune response against dying and dead cells. Curr Med Chem $14: 271-277$

49. Newsome TP, Scaplehorn N, Way M (2004) SRC mediates a switch from microtubule- to actin-based motility of vaccinia virus. Science 306:124-129

50. Ni M, Lee AS (2007) ER chaperones in mammalian development and human diseases. FEBS Lett 581:3641-3651

51. Ohashi K, Burkart V, Flohe S, Kolb H (2000) Cutting edge: heat shock protein 60 is a putative endogenous ligand of the toll-like receptor-4 complex. J Immunol 164:558-561

52. Orino K, Lehman L, Tsuji Y, Ayaki H, Torti SV, Torti FM (2001) Ferritin and the response to oxidative stress. Biochem $\mathrm{J}$ 357:241-247

53. Park SG, Jung G (2001) Human hepatitis B virus polymerase interacts with the molecular chaperonin Hsp60. J Virol 75:6962-6968

54. Pelkmans L, Puntener D, Helenius A (2002) Local actin polymerization and dynamin recruitment in SV40-induced internalization of caveolae. Science 296:535-539

55. Pressinotti NC, Klocker H, Schafer G, Luu VD, Ruschhaupt M, Kuner R, Steiner E, Poustka A, Bartsch G, Sultmann H (2009) Differential expression of apoptotic genes PDIA3 and MAP3K5 distinguishes between low- and high-risk prostate cancer. Mol Cancer 8:130

56. Radtke K, Dohner K, Sodeik B (2006) Viral interactions with the cytoskeleton: a hitchhiker's guide to the cell. Cell Microbiol 8:387-400

57. Saag MS, Holodniy M, Kuritzkes DR, O'Brien WA, Coombs R, Poscher ME, Jacobsen DM, Shaw GM, Richman DD, Volberding PA (1996) HIV viral load markers in clinical practice. Nat Med 2:625-629

58. Santoro MG (1994) Heat shock proteins and virus replication: hsp70 s as mediators of the antiviral effects of prostaglandins. Experientia 50:1039-1047

59. Scott FL, Hirst CE, Sun J, Bird CH, Bottomley SP, Bird PI (1999) The intracellular serpin proteinase inhibitor 6 is expressed in monocytes and granulocytes and is a potent inhibitor of the azurophilic granule protease, cathepsin G. Blood 93:2089-2097

60. Shoeman RL, Honer B, Stoller TJ, Kesselmeier C, Miedel MC, Traub P, Graves MC (1990) Human immunodeficiency virus type 1 protease cleaves the intermediate filament proteins vimentin, desmin, and glial fibrillary acidic protein. Proc Natl Acad Sci USA 87:6336-6340

61. Sloane BF, Yan S, Podgorski I, Linebaugh BE, Cher ML, Mai J, Cavallo-Medved D, Sameni M, Dosescu J, Moin K (2005) Cathepsin B and tumor proteolysis: contribution of the tumor microenvironment. Semin Cancer Biol 15:149-157

62. Stick R, Angres B, Lehner CF, Nigg EA (1988) The fates of chicken nuclear lamin proteins during mitosis: evidence for a reversible redistribution of lamin B2 between inner nuclear membrane and elements of the endoplasmic reticulum. J Cell Biol 107:397-406

63. Tang H, Peng T, Wong-Staal F (2002) Novel technologies for studying virus-host interaction and discovering new drug targets for HCV and HIV. Curr Opin Pharmacol 2:541-547

64. Thanthrige-Don N, Abdul-Careem MF, Shack LA, Burgess SC, Sharif S (2009) Analyses of the spleen proteome of chickens infected with Marek's disease virus. Virology 390:356-367

65. Todryk S, Melcher AA, Hardwick N, Linardakis E, Bateman A, Colombo MP, Stoppacciaro A, Vile RG (1999) Heat shock protein 70 induced during tumor cell killing induces Th1 cytokines and targets immature dendritic cell precursors to enhance antigen uptake. J Immunol 163:1398-1408

66. Trager W (1959) A new virus of ducks interfering with development of malaria parasite (Plasmodium lophurae). Proc Soc Exp Biol Med 101:578-582

67. Udono H, Srivastava PK (1993) Heat shock protein 70-associated peptides elicit specific cancer immunity. J Exp Med 178:1391-1396

68. Van Aelst L, D'Souza-Schorey C (1997) Rho GTPases and signaling networks. Genes Dev 11:2295-2322

69. Vorburger K, Kitten GT, Nigg EA (1989) Modification of nuclear lamin proteins by a mevalonic acid derivative occurs in reticulocyte lysates and requires the cysteine residue of the C-terminal CXXM motif. EMBO J 8:4007-4013

70. Wainberg Z, Oliveira M, Lerner S, Tao Y, Brenner BG (1997) Modulation of stress protein (hsp27 and hsp70) expression in CD4 + lymphocytic cells following acute infection with human immunodeficiency virus type-1. Virology 233:364-373

71. Wallin RP, Lundqvist A, More SH, von Bonin A, Kiessling R, Ljunggren HG (2002) Heat-shock proteins as activators of the innate immune system. Trends Immunol 23:130-135

72. Wang J, Fang S, Xiao H, Chen B, Tam JP, Liu DX (2009) Interaction of the coronavirus infectious bronchitis virus membrane protein with beta-actin and its implication in virion assembly and budding. PLoS One 4:e4908

73. Ward BM, Moss B (2001) Vaccinia virus intracellular movement is associated with microtubules and independent of actin tails. J Virol 75:11651-11663 
74. Watson A, Ranchalis J, Travis B, McClure J, Sutton W, Johnson PR, Hu SL, Haigwood NL (1997) Plasma viremia in macaques infected with simian immunodeficiency virus: plasma viral load early in infection predicts survival. J Virol 71:284-290

75. Witter RL, Smith EJ, Crittenden LB (1981) Tolerance, viral shedding, and neoplasia in chickens infected with non-defective reticuloendotheliosis viruses. Avian Dis 25:374-394

76. Witter RL, Li D, Jones D, Lee LF, Kung HJ (1997) Retroviral insertional mutagenesis of a herpesvirus: a Marek's disease virus mutant attenuated for oncogenicity but not for immunosuppression or in vivo replication. Avian Dis 41:407-421

77. Xue M, Shi X, Zhang J, Zhao Y, Cui H, Hu S, Gao H, Cui X, Wang YF (2012) Identification of a conserved B-cell epitope on reticuloendotheliosis virus envelope protein by screening a phage-displayed random peptide library. PLoS One 7:e49842
78. Xue M, Shi X, Zhao Y, Cui H, Hu S, Cui X, Wang Y (2013) Effects of reticuloendotheliosis virus infection on cytokine production in SPF chickens. PLoS One 8:e83918

79. Yan S, Sameni M, Sloane BF (1998) Cathepsin B and human tumor progression. Biol Chem 379:113-123

80. Yoshida I, Sakata M, Fujita K, Noguchi T, Yuasa N (1981) Modification of low virulent Newcastle disease virus infection in chickens infected with reticuloendotheliosis virus. Natl Inst Anim Health Q (Tokyo) 21:1-6

81. Zheng X, Hong L, Shi L, Guo J, Sun Z, Zhou J (2008) Proteomics analysis of host cells infected with infectious bursal disease virus. Mol Cell Proteomics 7:612-625

82. Zhou H, Xu M, Huang Q, Gates AT, Zhang XD, Castle JC, Stec E, Ferrer M, Strulovici B, Hazuda DJ, Espeseth AS (2008) Genome-scale RNAi screen for host factors required for HIV replication. Cell Host Microb 4:495-504 